\title{
Evaluation of short-term changes of hydrological response in mountainous basins of the Vitim Plateau (Russia) after forest fires based on data analysis and hydrological modelling
}

\author{
O. M. Semenova ${ }^{1,2}$, L. S. Lebedeva ${ }^{3}$, N. V. Nesterova ${ }^{2}$, and T. A. Vinogradova ${ }^{2}$ \\ ${ }^{1}$ Gidrotehproekt Ltd., St. Petersburg, Russia \\ ${ }^{2}$ St. Petersburg State University, St. Petersburg, Russia \\ ${ }^{3}$ Melnikov Permafrost Institute, Yakutsk, Russia \\ Correspondence to: O. M. Semenova (omakarieva@gmail.com)
}

Received: 12 March 2015 - Accepted: 12 March 2015 - Published: 12 June 2015

\begin{abstract}
Twelve mountainous basins of the Vitim Plateau (Eastern Siberia, Russia) with areas ranging from 967 to $18200 \mathrm{~km}^{2}$ affected by extensive fires in 2003 (from 13 to $78 \%$ of burnt area) were delineated based on MODIS Burned Area Product. The studied area is characterized by scarcity of hydrometeorological observations and complex hydrological processes. Combined analysis of monthly series of flow and precipitation was conducted to detect short-term fire impact on hydrological response of the basins. The idea of basin-analogues which have significant correlation of flow with "burnt" watersheds in stationary (pre-fire) period with the assumption that fire impact produced an outlier of established dependence was applied. Available data allowed for qualitative detection of fire-induced changes at two basins from twelve studied. Summer flow at the Amalat and Vitimkan Rivers ( 22 and $78 \%$ proportion of burnt area in 2003, respectively) increased by $40-50 \%$ following the fire.The impact of fire on flow from the other basins was not detectable.The hydrological model Hydrograph was applied to simulate runoff formation processes for stationary pre-fire and non-stationary post-fire conditions. It was assumed that landscape properties changed after the fire suggest a flow increase. These changes were used to assess the model parameters which allowed for better model performance in the post-fire period.
\end{abstract}

\section{Introduction}

Increasing intensity and number of forest fires in Russia are becoming a serious threat (Assessment Report on Climate Change, 2008). Though the studies of fire impact on environment have a long history in Russia, they mostly aim to assess the changes of vegetation (Lytkina, 2005), soil and permafrost (Tarabukina and Savvinov, 1990) or snow cover properties (Sabaeva, 2006) after fire and describe/predict the processes of forest succession and transformation of species diversity resulting from different types of fires (Isaev, 2011; Kharuk et al., 2008). Despite the fact that the effects of fire on catchment runoff response may be disproportionately strong compared to the area of burnt-out forest (Moody et al., 2008), the studies of those, such as abrupt changes of hydrologi- cal regime or the intensification of erosion processes that can lead to catastrophic flooding and even debris flows (Huscroft et al., 2004), are practically absent in Russia. Studies examining the impacts of clearcutting on hydrology are of some relevance, but are not entirely analogous with the impacts of fire on hydrological response (Onuchin et al., 2009, 2014; Krestovsky, 1986).

Following the studies by Lebedeva et al. (2014) and Semenova et al. (2015) who detected a short-term effect of fire on a small mountainous catchment in the Vitim River basin which resulted in significantly increased summer flow, this research aimed to broaden the scope of previous investigations from one basin to a larger area to reveal the similarities or differences of basins response to fire events depending on the size of catchments, share of burnt area and 
Table 1. The characteristics of the basins under study.

\begin{tabular}{|c|c|c|c|c|c|c|c|}
\hline $\begin{array}{l}\text { Gauge } \\
\text { code }\end{array}$ & River - outlet & $\begin{array}{c}\text { Basin } \\
\text { area, } \\
\mathrm{km}^{2}\end{array}$ & $\begin{array}{r}\text { Gauge } \\
\text { altitude, } \\
\mathrm{m}\end{array}$ & $\begin{array}{l}\text { Pairs of } \\
\text { basins } \\
\text { analogues }\end{array}$ & Period & $\begin{array}{r}\text { Annual } \\
\text { runoff, } \\
\mathrm{mm}\end{array}$ & $\begin{array}{r}\text { Burnt } \\
\text { area, } \\
\%\end{array}$ \\
\hline 3095 & $\begin{array}{l}\text { Vitim - } \\
\text { Ust'-Zaza }\end{array}$ & 14200 & 963 & & 1961-2011 & 169 & 51 \\
\hline 3096 & $\begin{array}{l}\text { Vitim - } \\
\text { Romanovkab }\end{array}$ & 18200 & 876 & Analogues & 1950-2011 & 157 & 49 \\
\hline 3109 & $\begin{array}{l}\text { Vitimkan - } \\
\text { Ivanovskiy }^{\mathrm{a}}\end{array}$ & 969 & 1250 & & 1957-2004 & 309 & 78 \\
\hline 3113 & $\begin{array}{l}\text { Zaza - } \\
\text { Ust'-Zaza }\end{array}$ & 1880 & 967 & & 1956-2011 & 70 & 49 \\
\hline 3117 & $\begin{array}{l}\text { Konda - } \\
\text { Elkiser }\end{array}$ & 5350 & 906 & & 1962-2011 & 48 & 67 \\
\hline 3118 & $\begin{array}{l}\text { Yumurchen - } \\
\text { Yumurchen }\end{array}$ & 3990 & 782 & & 1955-2011 & 141 & 41 \\
\hline 3119 & $\begin{array}{l}\text { Karenga - } \\
\text { Tungokochen }\end{array}$ & 3670 & 801 & Analogues & 1955-2011 & 138 & 72 \\
\hline 3120 & $\begin{array}{l}\text { Karenga - } \\
\text { Ust'-Karenga }^{d}\end{array}$ & 9460 & 654 & & 1965-1990, 2000-2011 & 129 & 28 \\
\hline 3127 & Tcipa - Uyu & 15600 & 1046 & Analogues & 1960-1990, 2000-2011 & 208 & 13 \\
\hline 3128 & $\begin{array}{l}\text { Tcipa - } \\
\text { Tcipikan }\end{array}$ & 5990 & 1086 & & $1960-2011$ & 212 & 33 \\
\hline 3130 & $\begin{array}{l}\text { Amalat - } \\
\text { Ust'-Antose }\end{array}$ & 2100 & 882 & Analogues & 1952-2011 & 120 & 22 \\
\hline 3131 & $\begin{array}{l}\text { Amalat - } \\
\text { Rassoshino }\end{array}$ & 8790 & 715 & & 1963-1990, 2000-2011 & 126 & 17 \\
\hline
\end{tabular}

$\mathrm{a} / \mathrm{b}, \mathrm{c} / \mathrm{d}, \mathrm{e} / \mathrm{f}, \mathrm{g} / \mathrm{h}$ are the pairs of basin analogues.

post-fire hydrometeorological conditions. We also developed the scenario of landscape transformation after fire, assigned the parameters of hydrological model accordingly and conducted simulations of daily flow for the Amalat River basin impacted by fire in 2003 for pre-fire and post-fire period. The difficulty of the research was conditioned by the scarcity of runoff data, the unrepresentativeness of precipitation measurements for vast mountainous territories and the absence of any specific observations.

\section{The study areaand data used}

The study catchments are located in the Transbaikal region of Russia which is a large and remote mountainous area to the east of the Baikal Lake (Fig. 1). It is characterized by high variety of climate and landscape conditions and forest fires are regularthere. Most part of the Vitim Plateau, the mountainous area where the left tributaries of the Vitim River go through, was subject to extensive forest fires in the spring of 2003. Based on monthly gridded $500 \mathrm{~m}$ MODIS Burned Area Product (MCD45) we delineated twelve gauged catchments with basin areas ranging from 969 to $18200 \mathrm{~km}^{2}$ affected by fire. Mainly the watersheds are covered by larch taiga.The hydrological regime of the studied area changes significantly from north-west to south-east direction. Steep- slope mountainous basins of the Ikatsky Ridge are underlain by continuous permafrost and have annual runoff of more than $200 \mathrm{~mm}$ (309 $\mathrm{mm}$ at the Vitimkan River) with precipitation reaching up to $600 \mathrm{~mm}$. The watersheds of the southeast get only $400 \mathrm{~mm}$ of annual precipitation which leads to much drier conditions and runoff decreases down to $100 \mathrm{~mm}$ or even less ( $48 \mathrm{~mm}$ at the Konda River). The characteristics of the basins are presented in Table 1. The climate of the studied area is severe continental with average annual air temperature about $-4{ }^{\circ} \mathrm{C}$. The region is situated at the border of continuous, discontinuous and isolatedpermafrost zones. More information on vegetation, soils and climate for the studied area is available in Semenova et al. (2015).

\section{Data analysis}

Very limited data is available for this remote region. There are twelve runoff gauges from which data could be used for long-term analysis and less than twenty meteorological stations with continuous series of observation covering about $70000 \mathrm{~km}^{2}$ area. The data contains monthly flow for the period 1966-2012 with the gap of 1990-1999 for some basins and monthly precipitation depths for continuous 1966-2012 period. 


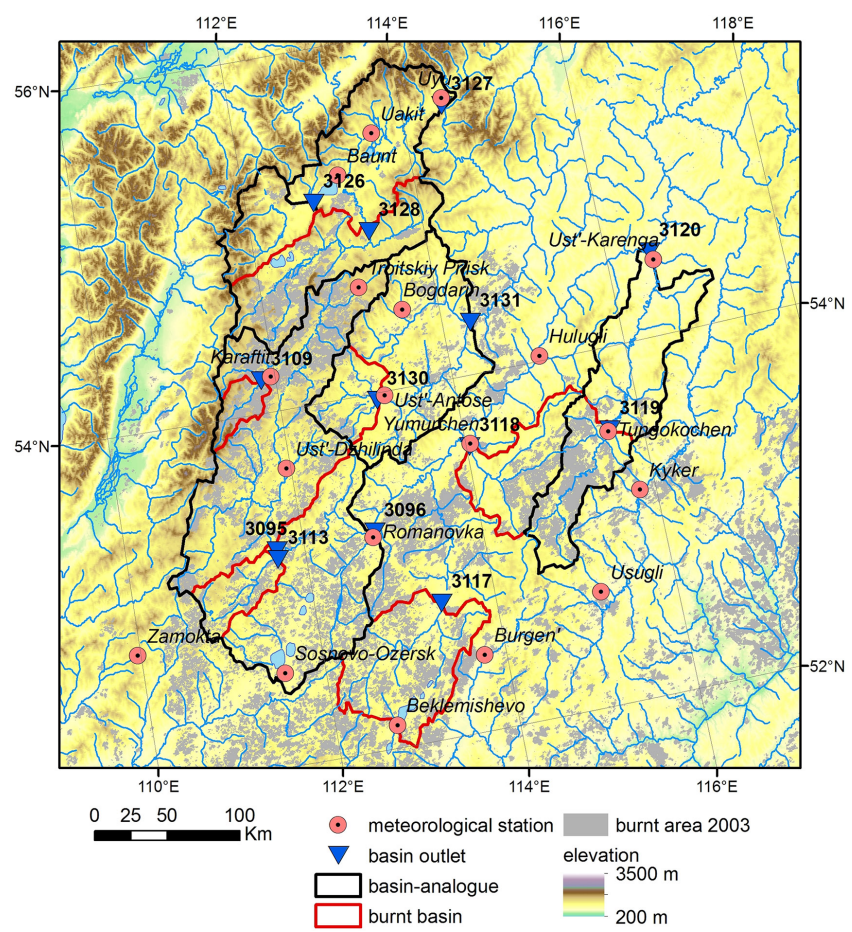

Figure 1. The scheme of studied area.

The assessment of fire effect on flow is conducted based on the use of basin-analogues which have significant correlation of flow with "burnt" watersheds in stationary (pre-fire) period. We assume that fire impact should produce an outlier of this established dependence. In the case of very limited datathe relativeness of the term "basin-analogue" should be taken into consideration. The effects of local precipitation on runoff generation are very high in mountains, so even in similar landscape conditions it turned out to be difficult to select basin-analogues. In this case the most reliable correlation of flow is observed flow from subbasin gauges. Four watersheds with extensive share of burnt area are the upper parts of larger basins. Those four pairs of watersheds were treated as the basin-analogues as they have meaningful mutual correlation of flow during warm season (June-September) with the values of $R^{2}$ varying from 0.83 to 0.90 .

Two fire-affected basins, namely the Tcipa River at Tcipikan and the Karenga River at Tungokochen with 33 and $72 \%$ share of burnt area, respectively did not behave differently to pre-fire conditions during 2003. However, summer flow at those two basins does not have close dependences on precipitation which are observed at nearest meteorological stations. Therefore, any short-term changes of water balance were not detected for the Tcipa and Karenga Rivers watersheds based on available monthly data.

On the contrary, two other basins, the Vitimkan River at Ivanovsky and Amalat River at Ust'-Antose with 78 and $22 \%$ share of burnt area, displayed expected fire-affected behavior. Strong correlation between flow for burnt and ana-

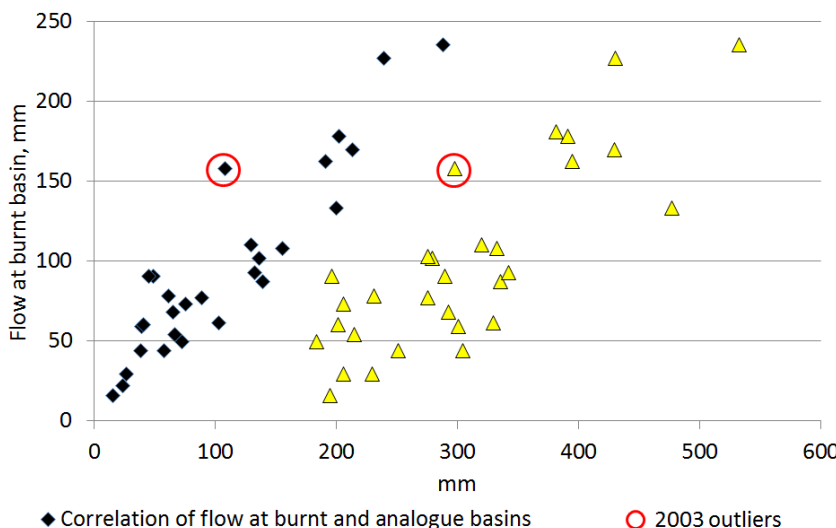

Correlation of flow at burnt and analogue basins
$\triangle$ Dependence of burnt basin flow on precipitation at meteorological station

Figure 2. The dependence of summer (June-September) flow at burnt and analogue basins; the dependence of summer flow at burnt basin on summer sum of precipitation at nearest meteorological station during stationary conditions and the dependences outliers caused by fire. Here burnt basin: Amalat River at Ust'-Antose (3130), analogue basin: Amalat River at Rassoshino (3131) and meteorological station - Ust'-Antose. 1966-1990 and 2000-2011.

logue watersheds within the stationary period is broken by 2003 dependence outlier. Summer flow during the warm season following spring fire was increased at those basins. According to Figs. 2 and 3 summer (June-September) flow in 2003 is heightened approximately by $40 \mathrm{~mm}$ at the Amalat River and more than $100 \mathrm{~mm}$ at the Vitimkan River. The presence of fire impact is confirmed by the defection of runoff precipitation dependence as well. In Figs. 2 and 3 one can see that during stationary periods summer flow has strong, though not linear, dependence on summer precipitation. 2003 is an outlier of such dependences at both basins suggesting that fire was the reason of changed patterns of flow. Interestingly, burnt area seems not to be the main factor determining basins response. The increase of flow at the Amalat River basin with $22 \%$ of burnt area is relatively higher (from expected 100 to observed $150 \mathrm{~mm}$ ) than at the Vitimkan River basin (78\% burnt area) where $41 \%$ flow increase was estimated by Semenova et al. (2015).We assume that relatively small size of the basins ( 969 and $2100 \mathrm{~km}^{2}$ ), the combination of vast burnt area fraction with strong precipitation at the Vitimkan River and moderate share of burnt area with maximum observed historical August precipitation at the Amalat River could lead to these unexpected hydrological consequences.

The lack of basin-analogues for the other three basins (the Zaza, Yumurchen and Konda Rivers), pronounced hysteresis type of the basins response to precipitation and generally drier conditions did not reflect the assessment of immediate fire impact on flow at monthly scale even though the shares of burnt area were rather high (49, 67 and $41 \%$, respectively). 


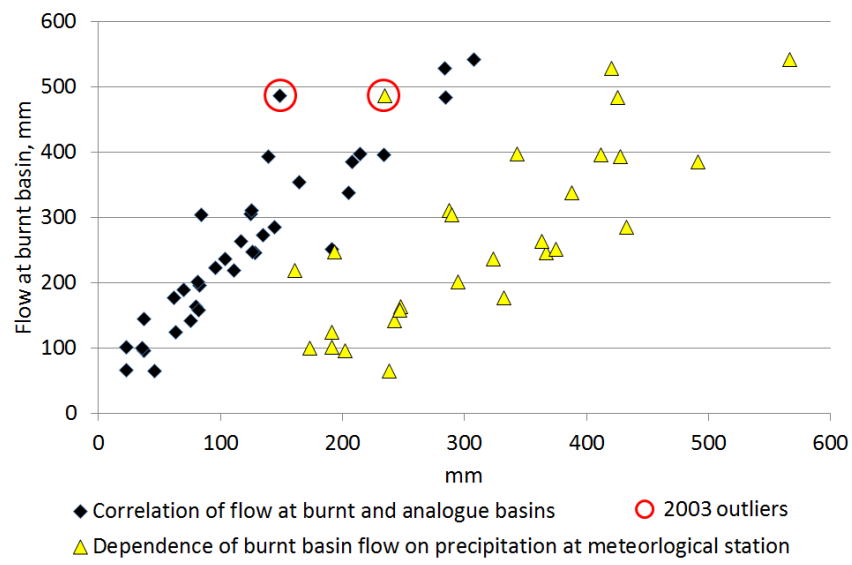

Figure 3. The dependence of summer (June-September) flow at burnt and analogue basins; the dependence of summer flow at burnt basin on summer sum of precipitation at nearest meteorological station during stationary conditions and the dependences outliers caused by fire. Here burnt basin: Vitimkan River at Ivanovsky (3109), analogue basin: Vitim River at Romanovka (3096) and meteorological station - Karaftit. 1967-2004.

\section{Hydrological modelling in non-stationary conditions}

Though hydrological models may be applied to detect the transformation of flow characteristics due to climate or landscape changes (ex., Seibert et al., 2010), future projections of hydrological behavior in non-stationary conditions based on the results of hydrological modelling are generally questionable (Semenova and Beven, 2015). This is because calibration of model parameters has become almost inevitable and rarely challenged part of modelling procedure.

Forest fires impact watersheds unexpectedly, their response to disturbance depending on many factors including the post-fire meteorological situation (Moody et al., 2013) and usually there are not enough data to calibrate the models for the post-fire environment. That is why new methods based on a priori comprehension of non-stationary processes are required for reliable projections of hydrological response.

Semenova et al. (2015) used the Hydrograph model (Semenova et al., 2013; Vinogradov et al., 2011) to detect and estimate immediate fire impact on flow and proposed the use of dynamic approach for hydrological modelling in post-fire environment for the Vitmkan River basin where only standard hydrometeorological data was available.

In the current study we conducted simulations of runoff formation processes for the Amalat River basin. It is situated close to the Vitimkan River basin (Fig. 1) and characterized by similar landscape conditions, therefore the set of the Hydrograph model parameters previously derived by Semenova et al. (2015) was applied, as well as the scenario of landscape properties transformation after fire in 2003. The scheme of Representative Points (RP) and runoff formation complexes

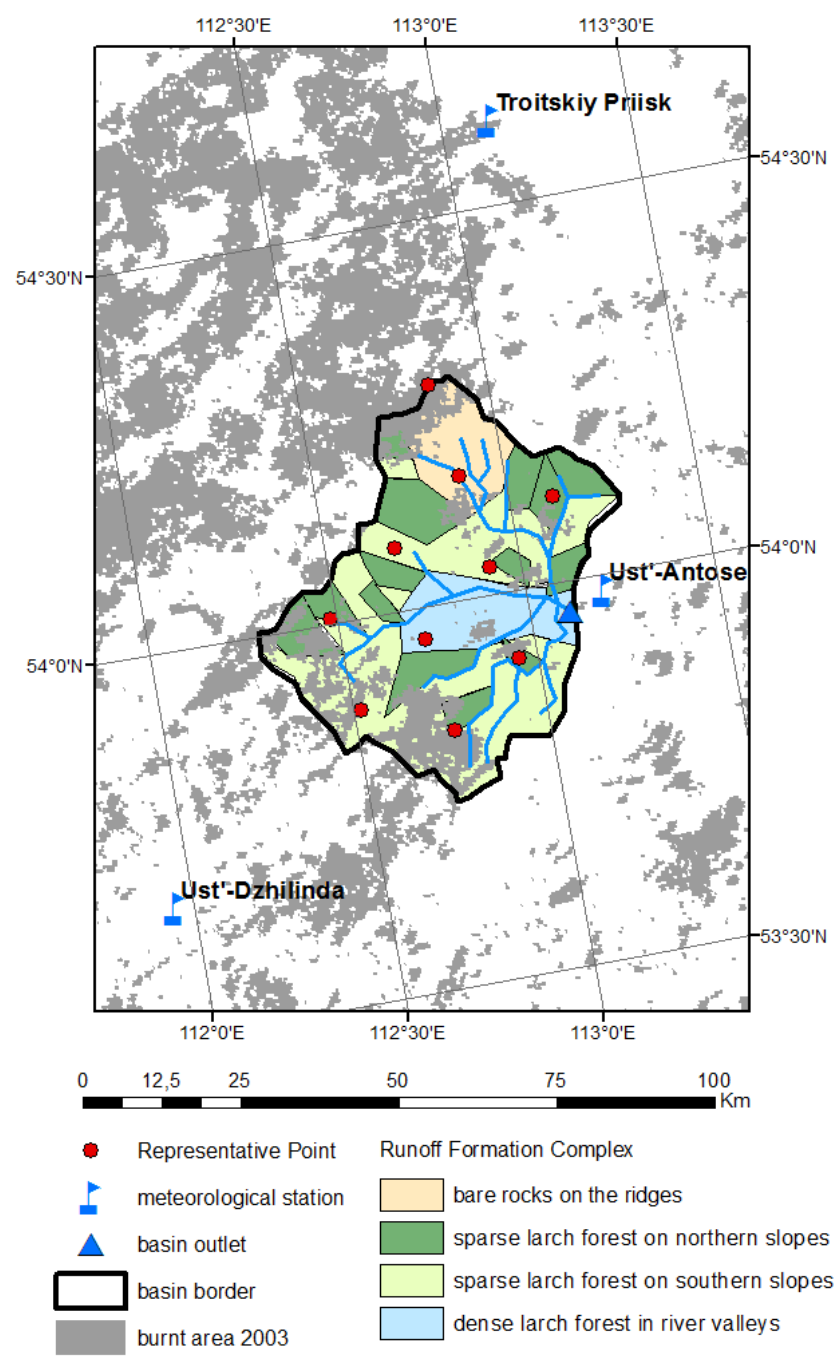

Figure 4. Schematization of the Amalat River basin for hydrological modelling.

(RFC), burnt area and the location of meteorological stations and runoff gauge for the Amalat River basin are shown at Fig. 4.

Continuous simulations of flow with pre-fire ("stationary") parameters were performed for 1966-2012 period (including fire year 2003) with Nash-Sutcliffe criteria varying from -4.6 to 0.93 and median value 0.50 . The examples of comparison of simulated and observed hydrographs for the years with poor/average/satisfactory simulation results and those for dry/average/wet years can be found at Fig. 5. One may note that for a mountainous basin with no meteorological station available within ist border, when main discrepancy of observed and simulated flow may be attributed to the lack of input data, obtained simulation results can be considered satisfactory and even good. Though increased discrepancy of modelling results from observed values in post-fire period at the Amalat River (Fig. 6) was not so obvious as in the case of 

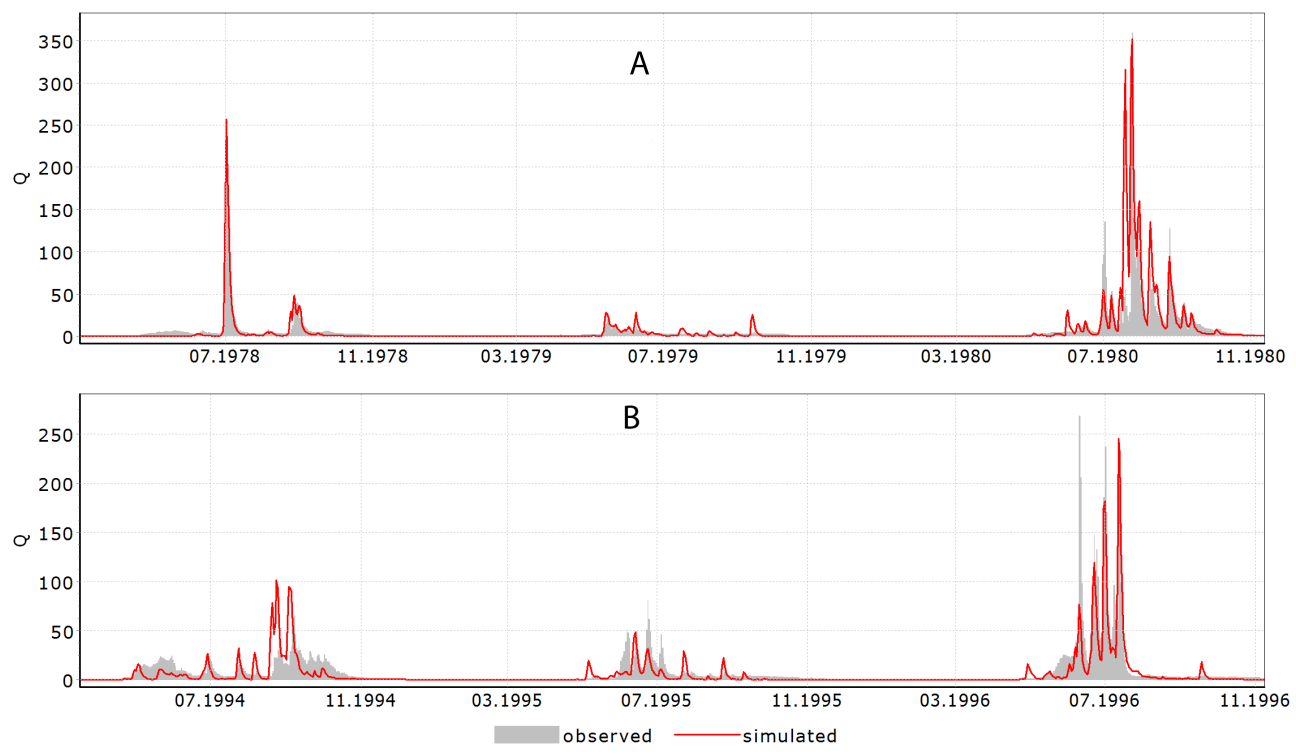

Figure 5. Observed and simulated hydrographs for the Amalat River at Ust'-Antose with "stationary" parameters: (a) average (1978), dry (1979) and wet (1980) years, (b) negative (1994), mean (1995) and high (1996) Nash-Sutcliffe value.

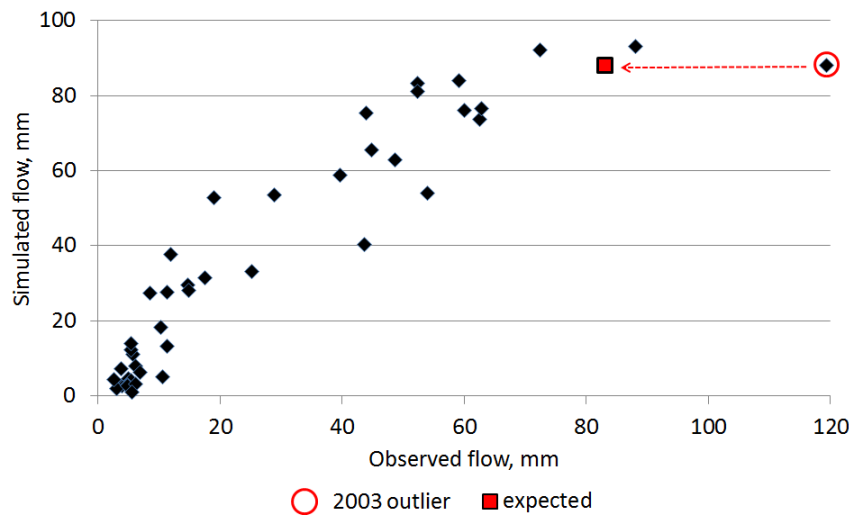

Figure 6. The dependence of observed and simulated flow depth in August for the Amalat River at Ust'-Antose with "stationary" parameters.

the Vitimkan River basin (Semenova et al., 2015), based on simulation results we speculate that up to $40 \mathrm{~mm}$ of observed flow depth in August 2003 can be attributed to flow increase due to fire impact.

Next step of the research was the application of the model parameters developed for post-fire conditions. These model parameter values were based on literature review of landscape properties changes as described by Semenova et al. (2015) and applied for the Amalat River here. The results of flow simulations with stationary and non-stationary parameters are presented in Fig. 7. They suggest the intensification of soil thaw due to change of surface energy balance (Jiang et al., 2015) and reduction of infiltration rate and evapotranspiration which in general lead to the increase of surface

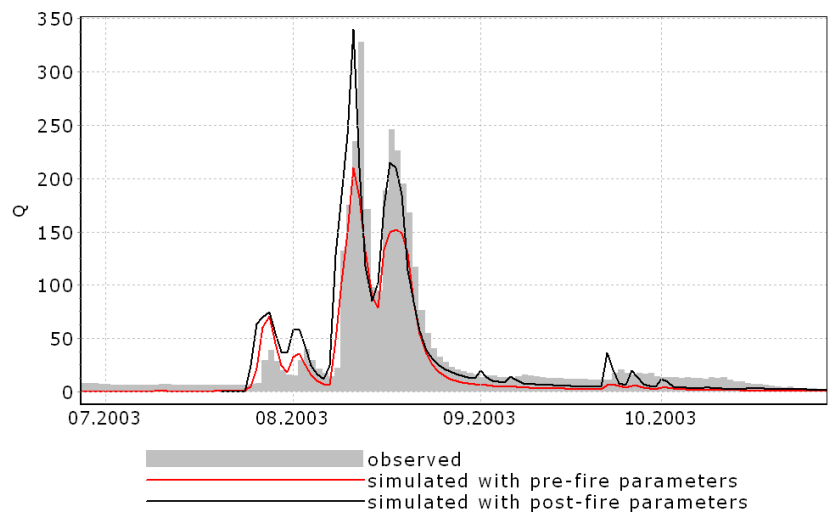

Figure 7. Comparison of observed and simulated hydrographs with the parameters assessed for pre-fire and post-fire periods. The Amalat River basin, 2003.

and preferential flow in soil horizons destroyed by fire (Koch et al., 2014) during summer flood events.

\section{Conclusions}

Siberian basins are subject to regular forest fires. Often little information is available about fires except their timing and areal distribution. Observed changes of hydrological response at burnt watersheds may serve as the only indirect quantitative evidence of soil, vegetation and permafrost transformation due to fire impact. The analysis of hydrological data and process scenario modelling may be used to reveal possible changes of landscape properties. 
Though Semenova et al. (2015) demonstrated for the Vitimikan River that short-term impact of fire on hydrological processes can be significant during extreme precipitation events, in most cases of limited meteorological data which does not allow for exact estimation of precipitation input at a mountainous watershed, the effects of fire on flow could be difficult to determine.

Available monthly flow and precipitation data for the studied region allowed for qualitative detection of fire short-term impact on flow at two basins from twelve studied basins in 2003. The impact expressed in increase of summer flow following the fire up to a $40-50 \%$.

The combination of several factors could lead to the shortterm transformation of hydrological regime, such as severity and extent of soil-vegetation disturbance and large precipitation events. Possible changes of physical mechanisms of runoff formation are discussed by Semenova et al. (2015), but the specification of each factor's input in those changes is impossible without additional information (for example, satellite data or field studies).

The approach to simulate changed hydrological processes based on a priori interpretation of possible landscape transformations used in this study is promising for application in hydrological modelling under non-stationary conditions, though very few models independent of calibration procedure can utilise such an approach. The Hydrograph model applied herein is one of them.

Acknowledgements. The study was partially supported by Russian Foundation of Basic Research (projects no. 14-05-00665 and 14-05-31194).

\section{References}

Assessment report on climate change and their impact in Russian Federation, Volume 2. Climate change impacts, Roshydromet, 289 pp., 2008

Huscroft, C. A., Lipovsky, P., and Bond, J. D.: Permafrost and landslide activity: Case studiesfrom southwestern Yukon Territory, in: Yukon Exploration and Geology 2003, edited by: Emond, D. S. and Lewis, L. L., Yukon Geological Survey, 107-119, 2004.

Isaev, A.: Natural and anthropogenic dynamics of permafrost larch forests with Yakutia as an example (in Russian), Phd. thesis, Yakutsk, 46 pp., 2011.

Jiang, Y., Rocha, A. V., O’Donnell, J. A., Drysdale, J. A., Rastetter, E. B., Shaver, G. R., and Zhuang, Q.: Contrasting soil thermal responses to fire in Alaskan tundra and boreal forest, J. Geophys. Res. Earth Surf., 120, 363-378, doi:10.1002/2014JF003180, 2015.
Kharuk, V., Ranson, K., and Dvinskaya, M.: Wildfires dynamic in the larch dominance zone, Geophys. Res. Let., 35, L01402, doi:10.1029/2007GL032291, 2008.

Koch, J. C., Kikuchi, C. P., Wickland, K. P., and Schuster, P.: Runoff sources and flow paths in a partially burned, upland boreal catchment underlain by permafrost, Water Resour. Res., 50, 81418158, 2014.

Krestovsky, O. I.: The impact of forest cutting and regeneration on river water content, Gidrometeoizdat, Leningrad, 119 pp., 1986 (in Russian).

Lebedeva, L., Semenova, O., and Volkova, N.: Assessment of wildfire impact on hydrological extremes in eastern Siberia, IAHS Publ., 363, 90-95, 2014.

Lytkina, L. P.: Dynamics of vegetation cover in burned larch forest in Lena-Amga interfluve, Central Yakutia, PhD thesis, Yakutsk, 200 pp., 2005 (in Russian).

Moody, J. A., Martin, D. A., Haire, S. L., and Kinner, D. A.: Linking runoff response to burn severity after wildfire, Hydrol. Proc., 22, 2063-2074, 2008.

Moody, J. A., Shakesby, R. F., Robichaud, P. R., Cannon, S. H., and Martin, D. A.: Current research issues related to post-wildfire runoff and erosion processes, Earth-Sci. Rev., 122, 10-37, 2013.

Onuchin, A. A., Burenina, T. A., Gaparov, Ê., and Ziryukina, N. V.: Land use impacts on river hydrological regimes in Northern Asia, Hydroinform. Hydrol., Hydrogeol. Water Res. IAHS, 331, 163-170, 2009.

Onuchin, A. A., Burenina, T. A., and Ziryukina, N. V., and Farber S. $\mathrm{K}$.: Impact of forest harvesting and forest regeneration on runoff dynamics at watersheds of Central Siberia, Forest J. Sib., 1, 110118, 2014 (in Russian).

Sabaeva, N. I.: Restoration of forest phytocenosis after the fire in conditions of Ishim region, south of Tyumen district, Phd. thesis, Omsk, 188 pp., 2006 (in Russian).

Seibert, J., McDonnell, J. J., and Woodsmith, R. D.: Effects of wild?re on catchment runoff response: a modelling approach to detect changes in snow-dominated forested catchments, Hydrol. Res., 41, 378-390, 2010.

Semenova, O. and Beven, K.: Barriers to progress in distributed hydrological modelling, Hydrol. Process., doi:10.1002/hyp.10434, 2015.

Semenova, O., Lebedeva, L., and Vinogradov, Yu: Simulation ofsubsurfaceheatandwaterdynamics, andrunoffgeneration in mountainouspermafrostconditions, in: the Upper Kolyma River basin, Russia, Hydrogeol. J., 21, 107-119, 2013.

Semenova, O., Lebedeva, L., Volkova, N., Korenev, I., Forkel, M., Eberle, J., and Urban, M.: Detecting immediate wildfire impact on runoff in a poorly-gauged mountainous permafrost basin, Hydrol. Sci. J., doi:10.1080/02626667.2014.959960, 2015.

Tarabukina, V. G. and Savvinov, D. D.: Influence of fires on permafrost soils, Novosibirsk, Nauka, 120 pp., 1990 (in Russian).

Vinogradov, Y., Semenova, O., and Vinogradova, T.: An approach to the scaling problem in hydrological modelling: the deterministic modelling hydrological system, Hydrol. Process., 25 1055-1073, 2011. 